\title{
Archaeological Monitoring of a Sidewalk Construction Project in Landa Park, New Braunfels, Comal County, Texas
}

John W. Arnn III

Center for Archaeological Research

Follow this and additional works at: https://scholarworks.sfasu.edu/ita

Part of the American Material Culture Commons, Archaeological Anthropology Commons, Environmental Studies Commons, Other American Studies Commons, Other Arts and Humanities Commons, Other History of Art, Architecture, and Archaeology Commons, and the United States History Commons

Tell us how this article helped you.

This Article is brought to you for free and open access by the Center for Regional Heritage Research at SFA ScholarWorks. It has been accepted for inclusion in Index of Texas Archaeology: Open Access Gray Literature from the Lone Star State by an authorized editor of SFA ScholarWorks. For more information, please contact cdsscholarworks@sfasu.edu. 


\section{Archaeological Monitoring of a Sidewalk Construction Project in Landa Park, New Braunfels, Comal County, Texas}

\section{Creative Commons License}

\section{(c) (1) \&}

This work is licensed under a Creative Commons Attribution-NonCommercial 4.0 International License 


\title{
Archaeological Monitoring of a Sidewalk Construction Project in Landa Park, New Braunfels, Comal County, Texas
}

\author{
John W. Arnn, III
}

Robert J. Hard and C. Britt Bousman

Principal Investigators

\section{๑copyright}

Center for Archaeological Research The University of Texas at San Antonio Archaeological Survey Report, No. 254 
The following information is provided in accordance with the General Rules of Practice and Procedure, Chapter 41.11 (Investigative Reports), Texas Antiquities Committee:

1. Type of investigation: Monitoring

2. Project name: Landa Park Sidewalk

3. County: Comal

4. Principal investigators: Robert J. Hard and C. Britt Bousman

5. Name and location of sponsoring agency: City of New Braunfels; 424 S. Castell; New Braunfels, Texas 78130

6. Texas Antiquities Committee Permit No.: n/a

7. Published by the Center for Archaeological Research, The University of Texas at San Antonio, 6900 N. Loop 1604 W., San Antonio, Texas 78249-0658, 1997

A list of publications offered by the Center for Archaeological Research is available. Call (210) 458-4378; write to the Center for Archaeological Research, The University of Texas at San Antonio, 6900 N. Loop 1604 W., San Antonio, Texas 78249-0658; e-mail to car@lonestar.utsa.edu; or visit CAR's Web site at http://www.csbs.utsa.edu/research/car/index.htm. 


\begin{abstract}
In February 1996, the Center for Archaeological Research of The University of Texas at San Antonio conducted monitoring for the construction of a handicap ramp in Landa Park, New Braunfels, Comal County, Texas. The work-required by the Texas Historic Commission-was performed under contract with the city of New Braunfels Parks and Recreation Department. The excavation of the footings for the handicap ramp covered an area roughly $2 \times 5 \mathrm{~m}$ and was less than $70 \mathrm{~cm}$ in depth. Over 2,600 prehistoric artifacts were uncovered including bone, fire-cracked rock, mussel shell, numerous platform and nonplatform flakes, cores, unifaces, several bifaces, and diagnostic projectile points. The diagnostic artifacts included Gower, Uvalde, Frio, Ellis, and Marcos projectile points as well as a Clear Fork biface and two Guadalupe bifaces. These diagnostics indicate at least three temporal assignments ranging from the Early Archaic to the Late Transitional Archaic periods. The artifacts were found in good archaeological and geological contexts despite the fact that the project area was in the midst of a heavily developed recreation area. The site has been assigned trinomial 41CM221.
\end{abstract}




\section{Contents}

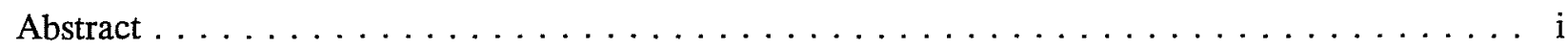

List of Figures $\ldots \ldots \ldots \ldots \ldots \ldots \ldots \ldots \ldots \ldots \ldots \ldots \ldots \ldots \ldots$ iii

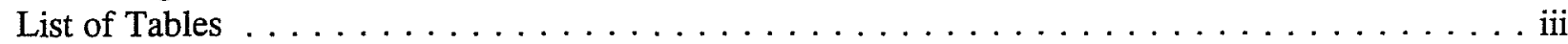

Acknowledgments $\ldots \ldots \ldots \ldots \ldots \ldots \ldots \ldots \ldots \ldots \ldots \ldots \ldots$ iv

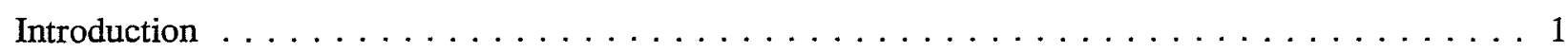

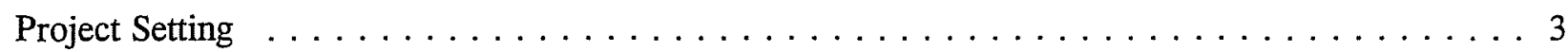

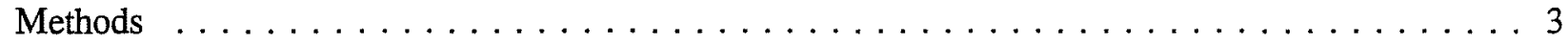

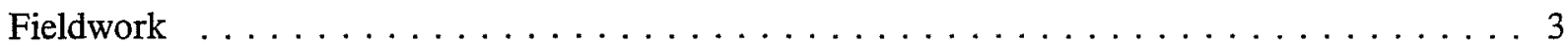

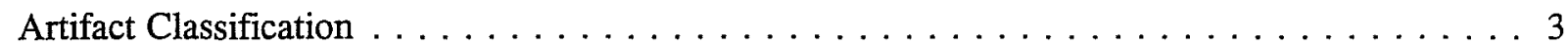

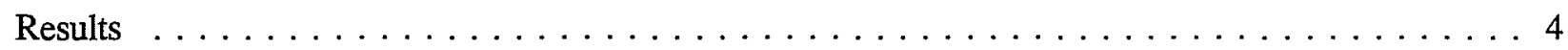

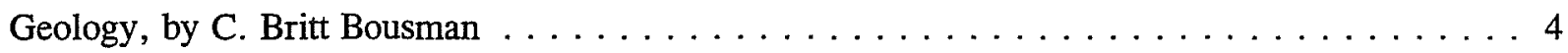

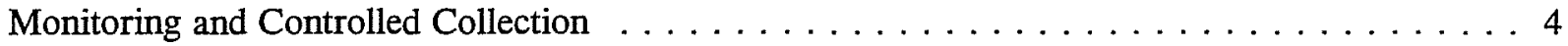

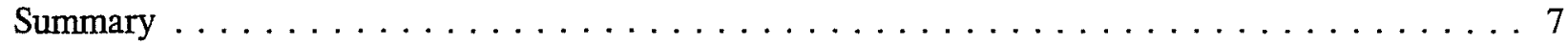

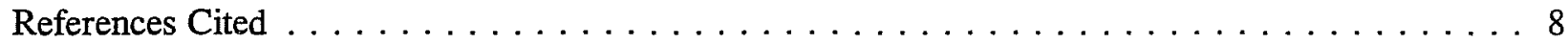




\section{Figures}

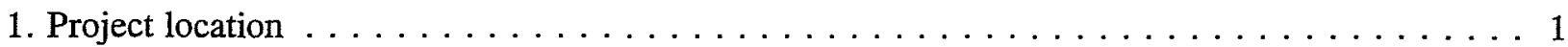

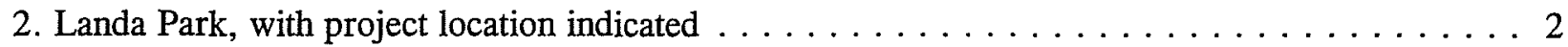

3. Diagnostic artifacts . . . . . . . . . . . . . . . . . . . 6

\section{Tables}

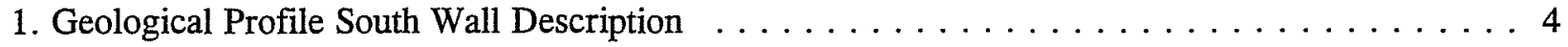

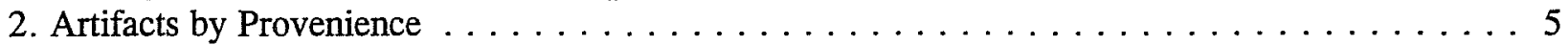




\section{Acknowledgments}

This project would not have been possible without the assistance and cooperation of Iris Haecker Neffendorf of the city of New Braunfels Parks and Recreation Department. Robert J. Hard and C. Britt Bousman served as principal investigators. Britt Bousman was instrumental in recording the geomorphology of the site and Bruce Moses must also be thanked for his fine drafting skills. Marcie Renner once again displayed superb editorial skills. Thank you to all of those involved in this project. 


\section{Introduction}

In February 1996, the Center for Archaeological Research (CAR) of The University of Texas at San Antonio conducted archaeological investigations in Landa Park, Comal County, Texas, for the city of New Braunfels (Figure 1). The Texas
Historical Commission did not require a Texas Antiquities Committee permit. CAR was responsible for monitoring excavations necessary for the construction of a handicap ramp in the immediate area of the boathouse in Landa Park (Figure 2). This report describes the results of those monitoring operations.

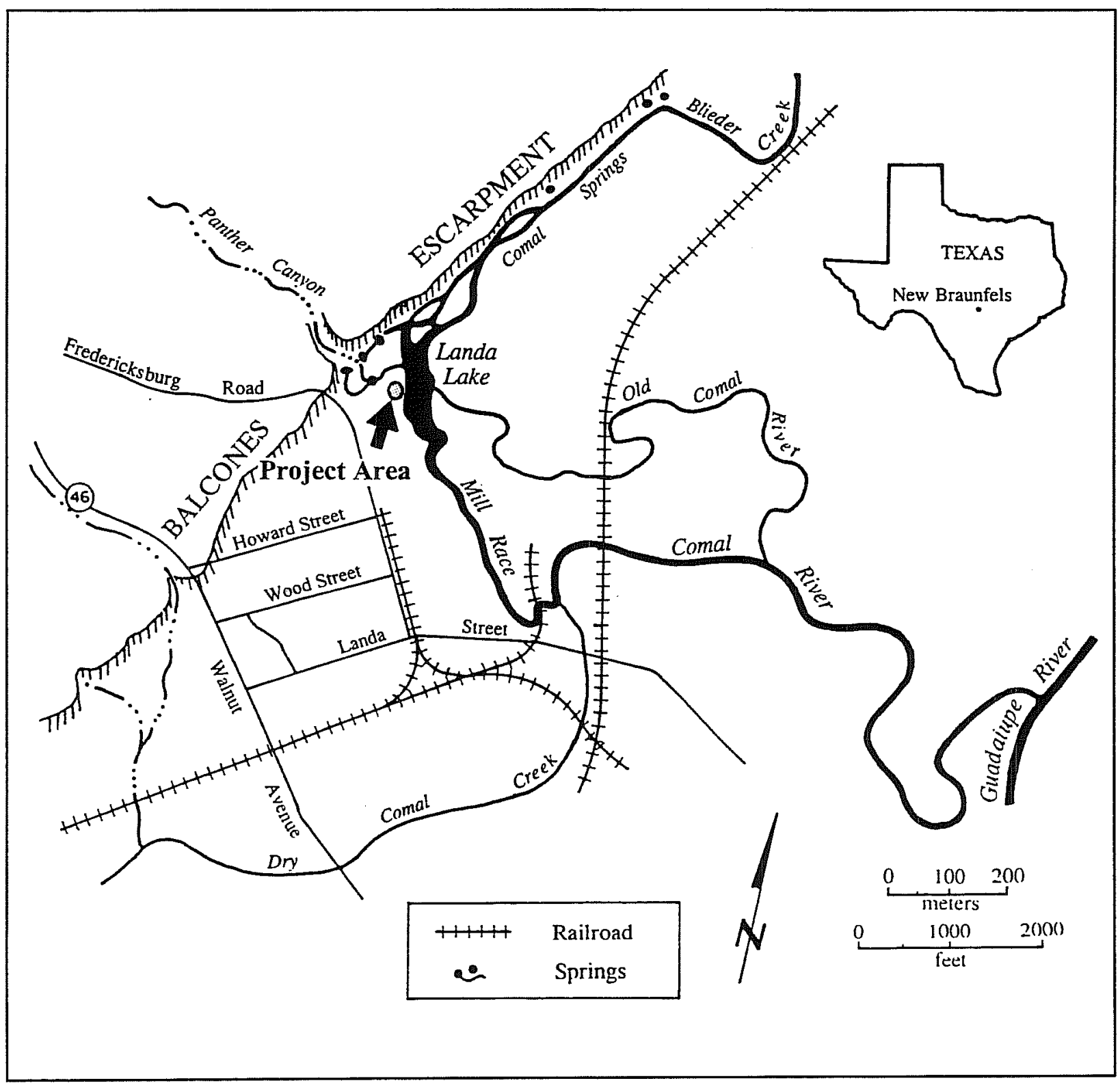

Figure 1. Project location. 


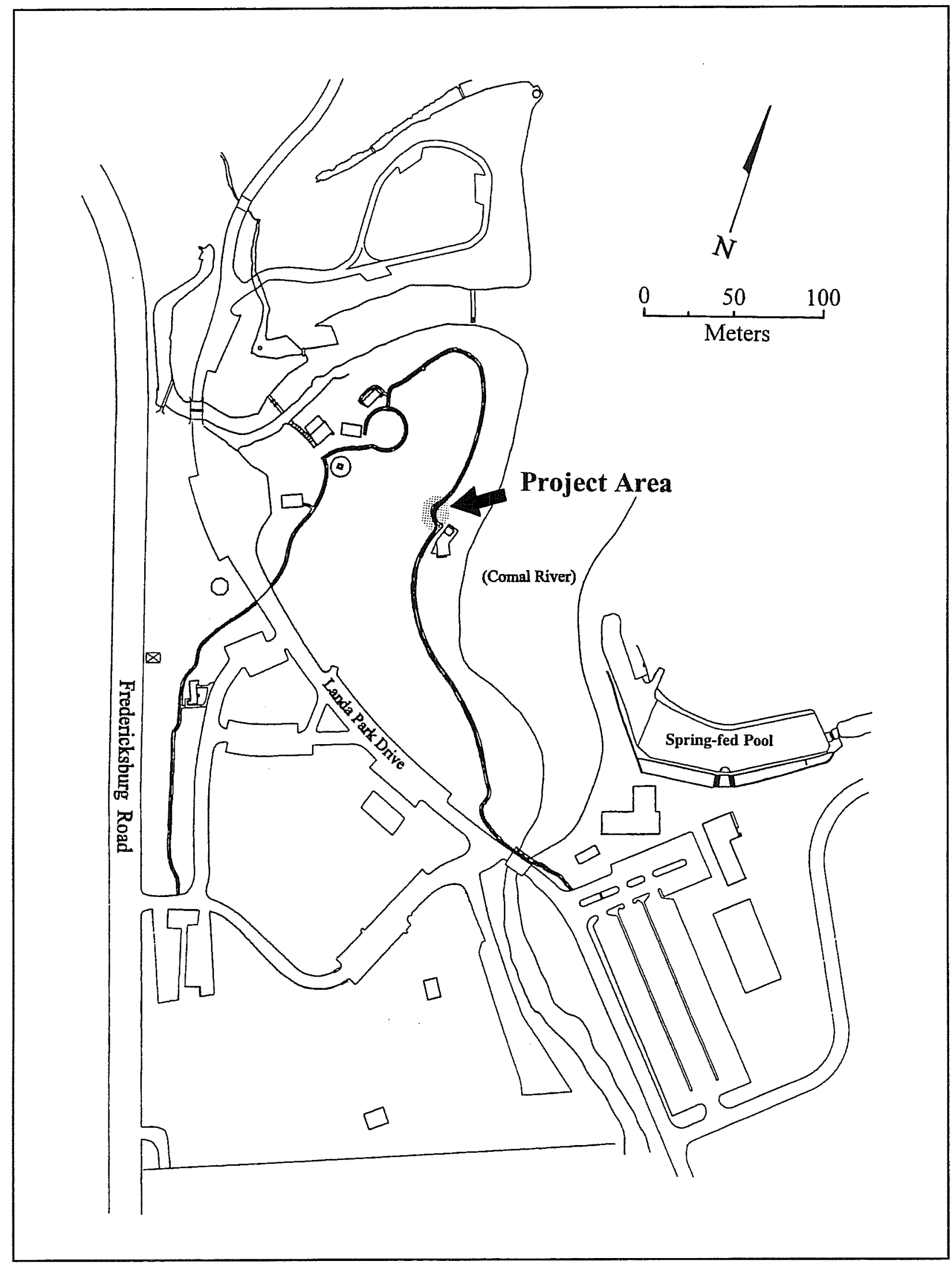

Figure 2. Landa Park, with project location indicated. 


\section{Project Setting}

The project area lies on the slope of a terrace, just west of Landa Lake and approximately $100 \mathrm{~m}$ east of the Balcones Escarpment. The lake appears to be the source of the Comal River, but is actually artificial, formed by the construction of a dam in the $1850 \mathrm{~s}$. The dam effectively pooled the flow from numerous springs in the immediate vicinity (Bailey and Bousman 1989:7). The springs themselves result from ground water outflowing through the Lower Cretaceous limestones of the Edwards Plateau and rising along fissures in the Balcones fault zone (Brune 1981:129).

The Balcones Escarpment marks the transition between the Edwards Plateau and the Blackland Prairie, as well as the convergence of numerous plant and animal species (Diamond et al. 1987). Ferdinand Roemer, one of the earliest chroniclers of the region, noted palmetto, red cedar, cypress, elm, mesquite, and oak trees (Roemer 1935). This is consistent with later accounts (Brune 1981; Haas 1968), particularly Bailey's. The latter describes the vegetation as a combination of southern Blackland Prairie and MesquiteChaparral Savanna (Bailey 1986:4).

The rich environment described above created an abundant and varied resource base as well as a predictable source of water for both prehistoric and historic peoples. Early historic accounts remark on the numbers of native peoples and the suitability of the area for colonization (Brune 1981; Roemer 1935). The archaeological record further strengthens these accounts. Excavations conducted by The University of Texas in 1936 by J. E. Pearce, A. T. Jackson, and A. M. Woolsey revealed a number of prehistoric burials less than $300 \mathrm{~m}$ from the project area (Pearce et al. 1936). Buried and surface deposits of burned rocks, mussel shell, and lithic artifacts occur with frequency throughout Landa Park and the immediate vicinity (Bailey 1986; Smith 1985). In addition, investigations at other spring sites along the Balcones Escarpment have revealed lithic and faunal material consistent with some of the earliest human activity in North America (Ricklis et al. 1991; Shiner 1983; Takac et al. 1992).

\section{Methods}

\section{Fieldwork}

The proposed construction called for making a cut approximately $2 \mathrm{~m}$ wide, $45 \mathrm{~cm}$ deep, and $5 \mathrm{~m}$ long. Originally the excavation was to be conducted by hand with personnel provided by the city; however, the construction crew conducted the excavation with a Bobcat mechanical scraper.

Two CAR archaeologists monitored the cut, which was made using a Bobcat with a bladed bucket. One person monitored the cutting while the other sifted the backdirt with the assistance of park personnel. When possible, artifacts were collected and sorted according to distinguished layers (see discussions below). After the monitoring was concluded, the construction crew apparently returned without notifying the archaeologists and excavated the cut at least an additional five meters in length and to an approximately depth of $70 \mathrm{~cm}$. The greatest depth occurred at the point where the terrace began sloping to the shoreline. Artifacts for this second unmonitored excavated were not available for analysis.

\section{Artifact Classification}

All projectile points were compared to the typological definitions and temporal assignments in Turner and Hester (1993). The Guadalupe tools were identified and classified using Brown (1985). The adzes were identified based on wear patterns following Semenov (1970:122-130). Nondiagnostic artifacts were classified as platform or nomplatform flakes, shatter, core, uniface, biface, heat-damaged chert, fire-cracked rock, mussel shell, and bone (Whitaker 1994). 


\section{Results}

\section{Geology}

\section{Britt Bousman}

A single profile was described on the south wall of the excavation (Table 1). The deposits and topographic situation indicate that an eroded and possibly disturbed surface soil (Zones 1 and 2) sits on a Cambric B-horizon that developed on a gravel deposit. The gravel zones (Zones 3 and 4) are in situ stream deposits and contain abundant archaeological materials. These zones have been altered by pedogenic processes to form Bhorizons. Zones 3 and 4 appear to have been deposited as channel gravels and overlying overbank alluvium, then later altered by pedogenesis and bioturbation. It is not evident that the gravels were deposited by the Comal River rather than a side tributary, but this is a likely possibility. Bedrock was not observed and the thickness of these alluvial deposits is unknown; however, abundant archaeological materials were observed throughout the intact alluvial deposits and these artifacts appear to be in good stratigraphic context. The depth of the archaeological materials is unknown. Approximately $10 \mathrm{~m}$ to the north along the bank of Landa Lake, at the same and slightly higher elevation as the described profile, is an indurated petrocalcrete gravel deposit. This deposit is much older than the alluvial sediments that contain prehistoric artifacts and it appears that a cut-and-fill sequence is marked by these two sedimentary units.

\section{Monitoring and Controlled Collection}

A total of 2,629 artifacts was recovered and classified according to depth and artifact type (Table 2). The artifacts tended to cluster at three depths and were assigned to levels based on provenience. The three levels were defined as 1) general scrapings: $0-13 \mathrm{~cm}$, surface and Zone 1

Table 1. Geological Profile South Wall Description

\begin{tabular}{|c|c|c|}
\hline Zone & Depth (cm) & Description \\
\hline 1 & $0-13$ & $\begin{array}{l}\text { Grayish brown (10YR 5/2) clay loam with limestone granules; fine subangular blocky } \\
\text { structure; few large limestone clasts; abundant roots and rootlets; few artifacts; clear, } \\
\text { smooth, and sloping boundary that follows the surface slope; possibly fill or disturbed } \\
\text { soil. }\end{array}$ \\
\hline 2 & $13-34$ & $\begin{array}{l}\text { Very dark gray (10YR 3/1) loamy clay, with common limestone granules and small } \\
\text { snail shell fragments; very abundant chert artifacts; rare bone; few roots and rootlets; } \\
\text { moderate subangular blocky structure; few limestone pebbles, some burned; clear, } \\
\text { smooth and sloping lower boundary; A-horizon. }\end{array}$ \\
\hline 3 & $34-48$ & $\begin{array}{l}\text { Reddish brown ( } 5 \text { YR } 5 / 4 \text { ) loamy clay; abundant fine-medium limestone stream-worn } \\
\text { gravels; abundant snail shells and fragments; abundant chert artifacts; } 3-5 \mathrm{~cm} \\
\text { diameter limestone pebbles; gradual smooth-sloping lower boundary that cross cuts } \\
\text { gravel lenses; B1-horizon. }\end{array}$ \\
\hline 4 & $48-67+$ & $\begin{array}{l}\text { Strong brown ( } 7.5 \text { YR } 5 / 6) \text { clay; abundant snail shell and chert artifacts; limestone } \\
\text { gravels slightly smaller than previous zone; lower boundary not observable; B2- } \\
\text { horizon. }\end{array}$ \\
\hline
\end{tabular}


Table 2. Artifacts by Provenience

\begin{tabular}{|c|c|c|c|c|c|c|c|c|}
\hline \multirow[t]{2}{*}{ Artifact Type } & \multicolumn{2}{|c|}{$\begin{array}{l}\text { General } \\
\text { Scrapings }\end{array}$} & \multicolumn{2}{|c|}{ Upper Level } & \multicolumn{2}{|c|}{ Lower Level } & \multicolumn{2}{|c|}{ Total } \\
\hline & $\mathbf{n}$ & $\%$ & $\mathbf{n}$ & $\%$ & $\mathbf{n}$ & $\%$ & $\mathbf{n}$ & $\%$ \\
\hline platform flake & 186 & 499 & 412 & 52.7 & 892 & $60 \% 2$ & 1490 & 565 \\
\hline nonplatform flake & 73 & 19.6 & 161 & 20.6 & 237 & 16.0 & 471 & 17.9 \\
\hline shatter & 18 & 0.3 & 15 & 1.9 & 42 . & 2.8 & 58 & 2,2 \\
\hline cores & 4 & 1.1 & 8 & 1.0 & 39 & 2.6 & 51 & 1.9 \\
\hline unifaces & 0 & 0.0 & 3. & 04 & 16. & 11 & 19 & 07 \\
\hline bifaces & 8 & 2.1 & 24 & 3.1 & 73 & 4.9 & 105 & 4.0 \\
\hline projectile points & 2 & $0.5 \%$ & 14 & 011 & 5 & $0 \%$ & 8 & 0.3 \\
\hline heat-damaged chert & 40 & 10.7 & 98 & 12.5 & 138 & 9.3 & 276 & 10.5 \\
\hline firecracked rock & 40 & 107 & 35. & 4.5 & 18 & 12 & 93 & 3.5 \\
\hline mussel shell & 17 & 4.6 & 14 & 1.8 & 14 & 0.9 & 45 & 1.7 \\
\hline bone & 11 & 03 & 9 & 1.22 & 6 & 04 & 16 & 0.6 \\
\hline other & 1 & 0.3 & 2 & 0.3 & 1 & 0.1 & 4 & 0.2 \\
\hline Total & 373 & & 782 & & 1481 & & 2636 & \\
\hline
\end{tabular}

sediments; 2) upper level: 13-34 cm, Zone 2; and 3) lower level: $34-67+\mathrm{cm}$, Zones 3 and 4. The levels were characterized by abundant concentrations of artifacts occurring in horizontal lenses at the depths given above. The upper and lower levels appeared to be in good geological and archaeological contexts. However, because the sediments were excavated with a Bobcat, the stratigraphic assignment of artifacts in the general scrapings level is tentative at best; this level may contain material from the other two.

Lithic material, particularly flakes, comprises the vast majority of the artifact collection. Platform flakes constitute 56.5 percent of all material collected, and nonplatform flakes make up 17.9 percent. The amount of shatter from all levels comprises just 2.2 percent. The relatively high frequency of bifaces ( 4.0 percent) compared to cores (1.9 percent), unifaces (0.7 percent), projectile points $(0.3$ percent $)$, and other artifacts (0.2 percent) suggests an emphasis on lithic reduction and tool production. The third-highest frequency is heat-damaged chert (10.5 percent), which was probably not related to the manufacturing process of stone tools. The low frequencies of fire-cracked rock (3.5 percent), mussel shell ( 1.7 percent), and bone ( 0.6 percent) relative to chert material tends to negate the idea of this site being the focus of food preparation, although these frequencies are not unusual for campsites in Central Texas. In terms of counts, the lower level had roughly twice as much cultural material as the upper level, and the upper level had roughly twice that of the general scrapings level. When viewed as percentages, the artifact frequencies between the three levels tend to be very close, within 10 percent (see Table 2). However, more fire-cracked rock and mussel shell were found in the general scrapings and upper levels than in the lower level.

The lower level also has higher frequencies in virtually every chert artifact type except non- 


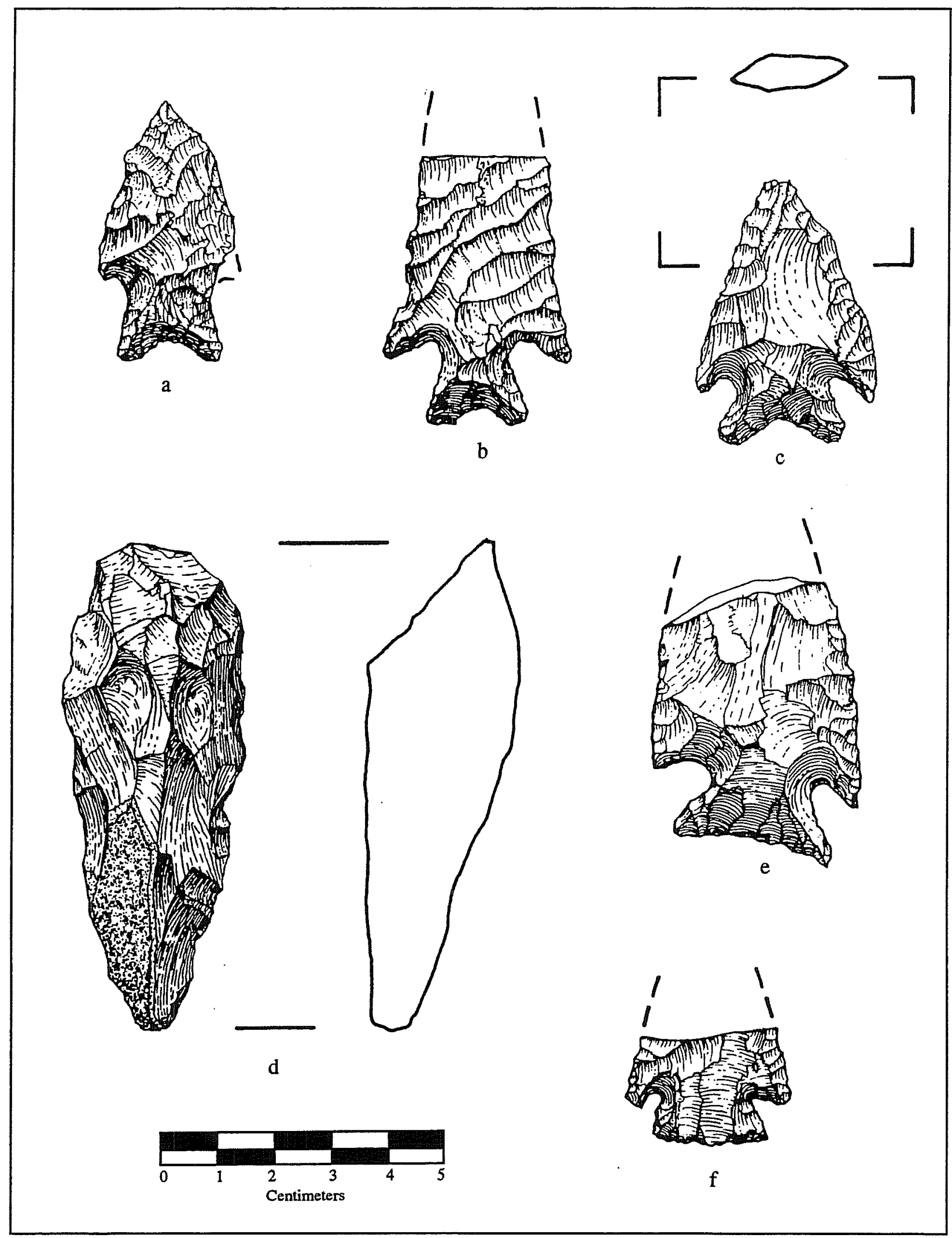

Figure 3. Diagnostic artifacts. a- Gower point; b- Uvalde point; c- Frio point; d- Guadalupe biface; e- Marcos point; f- Ellis point. 
platform flakes, projectile points, and heatdamaged chert. This information suggests a gradual shift in both the frequency and type of activity at the site through time.

Based on the diagnostic artifacts, the three levels have been tentatively assigned to chronological periods. The lower level was assigned to the Early Archaic based on the recovery of one Gower and one Uvalde projectile point (Figure $3 a$ and $b$ ), one Guadalupe biface, and two adze bifaces (one is a Clear Fork biface) (Turner and Hester 1993). The upper level was assigned the Middle to Late Archaic based on one Frio projectile point and one Guadalupe biface (Figure $3 c$ and $d$ ) (Turner and Hester 1993). Finally, the general scrapings level was assigned the Late to Transitional Archaic period based on the recovery of one Ellis and one Marcos projectile point (Figure $3 e$ and $f$ ) (Turner and Hester 1993).

\section{Summary}

This monitoring and collecting operation provided evidence for the existence of intact prehistoric cultural deposits in Landa Park. While previous investigations support the above statement, this particular project emphasized two points. First, extremely dense concentrations of cultural materials occur in intact geologic contexts, even in heavily developed areas of the park. Furthermore, this site has multiple occupations spanning thousands of years from the Early Archaic to Late Archaic periods. In light of these facts, 41CM221 is clearly significant and is recommended for nomination to the National Register of Historic Places. 


\section{References Cited}

Bailey, G. L.

1986 Archaeological Investigations in Landa Park, City of New Braunfels, Comal County, Texas. Letter Report No. 330. Prewitt and Associates, Austin.

Bailey, G. L., and C. B. Bousman

1989 Subsurface Archaeological Survey and Monitoring of the Landa Street/Fredericksburg Road Drainage Improvement Project, Comal County, Texas. Technical Reports No. 6. Prewitt and Associates, Austin.

Brown, K.

1985 Three Caches of Guadalupe Tools from South Texas. Bulletin of the Texas Archeological Society 56:75-125.

Brune, G.

1981 Springs of Texas. Vol. 1. Branch-Smith, Fort Worth.

Diamond, D. D., D. H. Riskind, and S. L. Orzell

1987 A Framework for Plant Community Classification and Conservation in Texas. The Texas Journal of Science 39:3:203-221.

Haas, $\mathrm{O}$.

1968 The History of New Braunfels and Comal County, 1844-1946. Steck, Austin.

Pearce, J. E., A. T. Jackson, and A. M. Woolsey

1936 Notes on Field Work, H. C. Locke Farm, 1 Mile West of New Braunfels, Comal County, Texas. Manuscript on file. Texas Archeological Research Laboratory, The University of Texas at Austin.

Ricklis, R. A., M. D. Blum, and M. B. Collins

1991 Archeological Testing at the Vera Daniel Site (41TV1364), Zilker Park, Austin, Texas. Studies in Archeology 12. Texas Archeological Research Laboratory, The University of Texas at Austin.

Roemer, F.

1935 Roemer's Texas. Texian, San Antonio

Semenov, S.A.

1970 Prehistoric Technology. Redwood, London.

Smith, $\mathrm{H}$.

1985 An Assessment of Archaeological Resources in Landa and Cypress Bend Recreation Areas, New Braunfels, Texas. Manuscript on file. Texas Historical Commission, Austin.

Shiner, J. L.

1983 Large Springs and Early American Indians. Plains Anthropologist 28:1-7. 
Takac, P. R., P. Goldberg, and S. Valastro

1992 Archeological and Geomorphological Testing Along the Proposed South Austin Outfall Relief Main, Phase II Tunnel Alignment: The Vara Daniel Site (41TV1364), Zilker Park, Austin Texas. Technical Series 28. Texas Archeological Research Laboratory, The University of Texas at Austin.

Turner, E. S., and T. R. Hester

1993 A Field Guide to Stone Artifacts of Texas Indians. Second edition. Gulf, Houston.

Whitaker, J. C.

1994 Flintknapping, Making and Understanding Stone Tools. University of Texas Press, Austin. 
